\title{
Lusophone community in the digital age: the ambiguous place of scepticism and performance
}

Helena Sousa, Communication and Society Research Centre, University of Minho helena@ics.uminho.pt

Keywords: Academia, community, language, Lusophony, media policy, Portugal

This paper addresses the setting up of the political Community of the Portuguese Language Countries (CPLP - Comunidade dos Países de Língua Portuguesa) and its present-day social and cultural dynamics. As the other articles in this Special Section from Martins, Salgado and Santos also demonstrate, media and communication systems are playing a role in the development of this loose aggregation and in the internal dynamics of the Portuguese language countries.

In this paper, I will highlight the difference between the political and geostrategic moves that led to the formal constitution of the official Lusophone Community in 1996 (Angola, Brazil, Cape Verde, Guinea-Bissau, Mozambique, Portugal and Sao Tome and Prince) and the rich and diverse civil society dynamics that are not necessarily articulated with wider geo-political and economic interests (East-Timor and Equatorial Guinea joined the CPLP in 2002 and 2014, respectively).

Indeed, two movements can be observed in this fluid and often conflicting process: one is the top-down political decisions aiming to reconfigure institutional arrangements and to promote Lusophony as a strategically meaningful global construct; the other one is a multitude of small-scale arrangements and bottom-up efforts to connect and associate Portuguese speaking people creating new and richer inter-cultural significance for their activities and achievements.

In this text I will firstly address the political consensus that was established in Portugal regarding the importance of the Lusophone Community. I will then present some aspects of the academic scepticism (still very much alive) regarding this post-colonial construct and lastly I will signal the bottom up inter-continental Lusophone dynamics possibly quite indifferent to the Portuguese political consensus and the on-going academic debates.

\section{Political Consensus}

On the 17th of July 2016 the Portuguese Minister for Foreign Affairs, Augusto Santos Silva, published an opinion article in the daily newspaper Público (p. 16) celebrating the $20^{\text {th }}$ anniversary of the Portuguese Language Community Countries (CPLPComunidade dos Países de Língua Portuguesa). The importance attributed by the Portuguese authorities to this community of sovereign countries, with the same rights and duties, has been a critical and largely consensual trait of the Portuguese foreign policy over the last two decades. 
Despite the long overdue decolonization process in the mi-1970s (subsequent to independence wars in Angola, Mozambique and Guinea-Bissau), by the mid-1980's diplomatic efforts were put in place to set up a community of Portuguese language countries. A decade of negotiation ended up in the formal constitution of the CPLP. On the 17 July of 1996, the heads of state and heads of government of the Portuguese Language Countries signed, in Lisbon, the CPLP agreement. Twenty years after the Revolution, the wounds of the independence wars were healing and a new relationship could be built. Multi-party systems were being implemented in Africa and Brazil was keen to put the Portuguese language in the globalization dynamics.

This political community that was defined as a 'privileged multi-lateral forum to deepen mutual friendship, to co-ordinate political and diplomatic strategies and to develop cooperation amongst its members' (Comunidade dos Países de Língua Portuguesa, 1996, Article 1). Universal principles like peace, freedom, human rights, democracy, social justice, parity amongst members were put forward as CPLP's underlying objectives. Up to this day, notwithstanding major difficulties, all Portuguese governments (conservative, socialists and presently socialists backed by the Left Bloc and Communist Party) supported the CPLP.

The media (information and fiction) have always been in the agenda of the CPLP members. Portugal paid special attention to it (Sousa, 2000, 2005). In 1987, one year after the accession to the European Union, the first majority government since the 1974 Revolution (Cavaco Silva was prime-minister), considered Brazil and the Portuguese speaking African countries worthy of utmost attention. In the government's programme section concerning the media, it was argued that attention should be given to the necessary reinforcement of linkages between the various spaces of the Portuguese presence in the world (Assembleia da República, 1987, Part IV, point 4). Four years later, an international public service channel (RTP Internacional - RTPi) gave a new impetus to the process 'to strengthen cooperation links, to reinforce our universal matrix and to give added value, defend and project our language and culture in the world' (Assembleia da República, 1992, Part III, point 7).

In line with the previous social democrat government, the António Guterres' socialist government (1995-1999) reaffirmed the relevance of the Portuguese media in the Lusophone context. In the media field, this government tried to improve coordination between RTPi, the public service radio (RDP Internacional) and the national news agency Lusa. António Guterres wanted to go further in the internationalization of Portuguese cultural works and national artists and, in addition to a number of cultural actions which 'might project Portugal in the world' (Assembleia da República, 1999, Part I).

The next two short-lived centre-right governments (led by Durão Barroso and by Santana Lopes, from 2002 to 2004 and from 2004 to 2005, respectively) followed the same line. The Lusophone space, namely Brazil, Portuguese speaking African countries and East-Timor (joined CPLP after its independence 2002), was at the very heart of these governments external policy and the affirmation of the Portuguese Language and culture was extremely high on the agenda. At this stage, the purpose was not merely to reinforce the relationship with these countries but to 'reinforce the privileged 
relationship' with the Lusophone space (Assembleia da República, 2002, Part I, 2).

Neither the socialist governments (2005-2011), led by José Sócrates, nor the conservatives led by Passos Coelho (2011-2015) diverged from previous discourses on Lusophony (Assembleia da República, 2005; 2011). Both discourses and political actions revealed a rare political convergence. The political convergence has however been in clear contrast with academic suspicion from Lusophone academia (sometimes critical of the Lusophone concept itself).

\section{Academic Scepticism}

The concept of Lusophony gained intellectual relevance only from the mid-1980's onwards. Just like Francophony and Anglophony, it is a post-colonial concept which incorporates geographically dispersed regions sharing the same language. According to Léonard, Lusophony has at least three inter-related interpretations. Firstly, Lusophony is a geo-linguistic space, that is, a number of highly dispersed regions, countries and societies whose official and/or maternal language is Portuguese. Secondly, Lusophony is a sentiment, a memory of a common past, a partition of common culture and history. Thirdly, it is a set of political and cultural institutions attempting to develop the Portuguese language and culture in Portuguese speaking spaces and fora (1999: 438).

Bringing back colonial memories, the use of the concept by political actors and its appropriation by civil society met profound scepticism from academics. Baptista (2000) has argued that Lusophony is a good concept to abandon because it is a notion that has 'The Lusiads' (considered the finest work in Portuguese literature written by Luís de Camões in 1572) and 'Lusus' (the founder of Lusitania, the Roman province that roughly corresponds to modern Portugal) at its centre-stage. According to Baptista, despite the official rhetoric, the concept of Lusophony cannot be perceived as 'innocent'. The author backs one of the most important contemporary Portuguese philosophers, Eduardo Lourenço, who is sceptical of the Lusophone movement: 'We cannot be neither hypocritical nor voluntarily blind: the dream of a Portuguese language community, finely or poorly dreamed, is by nature - which is above all history and mythology - a dream whose root, structure and purpose is related with the Lusiad amplitude' (in Baptista, 2000: 1).

For Lourenço, there are two fundamental aspects which cannot be ignored when discussing the concept of Lusophony: language and culture. In relation to language, it is fundamental to recognize the extreme diversity of the Portuguese language in the various countries whose official language is Portuguese. In countries such as Brazil, for example, Portuguese is the maternal language. In other countries, such as East-Timor, Angola and Mozambique, there are significant segments of the populations for whom Portuguese is an unknown foreign language. In a symbolic (here perceived as cultural) perspective, Lourenço believes that for the Portuguese people, it fulfils an imaginary space of imperial nostalgia so 'we can feel less isolated and turn out to be more visible in the world' (Lourenço, 1999: 181), given that the imperial cycle is definitely over.

In different but also critical ways, authors such as Alfredo Margarido (2000, 2007), Claudia Castello (1998) and Miguel Vale de Almeida (2002) express their scepticism 
regarding the Lusophone neo-colonial (more or less subtle) political dynamics and interests. The importance of these academic perspectives should be recognized as they try to deconstruct and denaturalize Luso-centric and Euro-centric underlying assumptions. However, the ideological underpinning of Lusophony and the political and strategic interests do not fully explain the present-day complexities of Lusophony.

According to Martins (2004), Lourenço's perception of Lusophony as an imaginary refuge or as a nostalgic sanctuary does not fully account for the comprehensiveness of the 'Lusophone dream'. Martins believes that in present-day global world the most fundamental social infrastructures are not markets or technologies but 'cosa mentale', deep social imaginings. This is why he sees Lusophony as fundamentally a cultural space. 'As a cultural space, Lusophony take us to the fundamental anthropological reality, to the human indicator that is the imaginary of territorial landscapes, traditions and language' (2004: 2). In this sense, Lusophony is the territory of cultural archetypes, a mythic basis which nourishes collective dreams. Looking at Lusophony as a cultural space, Martins concentrates his analysis on it's mythic, symbolic and imaginary dimensions. In this sense, the Lusophone space has a mythological foundation and an unconscious basis.

Talking this understanding of culture, myth shapes history. 'It is the myth that fulfils history with concrete reality, with memory and human meaning. Understood as myth and symbolic imaginary, culture is imagined collective life and a common route (...). Is it by sharing imaginings and visions of the future that hypothesis are put in place for the choices which are to be made' (Martins, 2004: 4). If one takes Lusophony as a memorybased construct steered by visions of the future, it becomes less pertinent as a Luso(Portuguese)-centric concept. If Lusophony can be perceived and appropriated in terms of plurality and difference, it might easier to understand its pragmatic capacity.

\section{People's Pragmatism}

Indeed, most research on Lusophony has so far focused on the examination of the symbolic dimensions of Lusophony and on the formal top-down Lusophone political and economic structures. Bottom up initiatives have not yet received yet sufficient attention from the academy despite the proliferation of micro communities calling themselves 'Lusophone'. Being a communicative space, it is a practical reality for millions of people across four continents. Lusophone associations, networks, entities (formal and informal) are flourishing and therefore Lusophone dynamics are identifiable in all social areas (cultural activities, sports, health, human rights, environment, business, academic). Authors paying particular attention to the bottom up analysis of concrete communities within the wider Lusophone framework (e.g. Maciel, 2010; Macedo, 3013, Salgado, 2014 and Martins, 2015) are introducing new alternative insights that enrich the understanding of Lusophony as a communicative and cultural space.

The PhD. Dissertation of Macedo (2013) has shown that digital networks and online spaces have been set up and are facilitating communication between citizens who think, feel and speak in the same language. Being the $5^{\text {th }}$ most used language on the internet 
Portuguese is used in thousands of sites, blogs and digital fora where people have the possibility to articulate interests and to develop synergies. Millions of Portuguese speaking people are digitally connected which engenders different possibilities, new tensions and new solidarities. Basically, the thesis shows that the Portuguese language has inundated the internet and this is bound to have cultural and social consequences.

Departing from a more sceptical approach, Maciel (2010) also recognizes in her $\mathrm{PhD}$ thesis that present-day dynamics of Lusophone communities need to be approached from bottom up if one wishes to grasp its intricacy. Despite the ideological basis of the Lusophone project and the motives for its creation and its modus operandus, Maciel demonstrates that the Lusophone Community seems to be more than a space that brings back memories of exploitation, indifference and conflict. She argues that given new possibilities of globalization, the Lusophone community expresses new dynamics and synergies (Maciel, 2010). Amongst other relevant insights, Maciel (2010) looks at the top-down development of two Lusophone institutions (Instituto Português do Livro e das Bibliotecas based in Portugal and the Instituto Internacional de Lingua Portuguesa based in Cape Verde) and show the bottom up appropriation of these institutions by citizens in the (re)construction of their own identities and communities.

Taking a pragmatic and multiculturalist approach, Martins (2015) details the setting up and development of the Lusophone Federation of Associations of Communication Sciences (Lusocom) in 1998. This academic institution connects students, researchers and teachers from Portuguese official language countries. Lusocom aims to promote the development of Communication Sciences in the Lusophone geo and cultural region, to encourage cooperation between Portuguese speaking countries, to increase the international role of the Portuguese speaking researcher's communities in terms of scientific production and to sponsor the publication of scientific work in Portuguese. Beyond regular scientific meetings and multiple academic exchanges, Lusocom managed to regularly publish the Anuário Internacional de Comunicação Lusófona (International Yearbook of Lusophone Communication) and it has encouraged and supported various Portuguese language scientific publications.

Today Lusophony is a de facto plural community based on practical interests that deserves attention from the academia both at national and international level. The pragmatic dimension of the Lusophone Community with its contradictions, ambiguities, resistances and homogenies, nostalgias and utopias has much to offer to the wider analysis of the performative potential of memory. It is nevertheless critical that both academics, politicians and civil society resist to the idea of an artificial unity because the shared discursive patrimony is both divergent and convergent. Lusophony has a performative effect but it is not unidirectional - its transformative capacity depends of the imaginary of very different communities in different continents.

Summing up, this article tried to clarify that the political existence of the Lusophone political community per se does not explain the growing vitality of Lusophone movements, networks and associations. Quite distinctively, I argued that that it is through language that communities are permanently reconstructed and therefore they might either be in line with the political Lusophone community aims or indeed they might be relatively indifferent or even opposed to them. Lusophony is a political 
construct formally recognized since 1996 but it is also a fast-changing plural community based on everyday practical interests.

\section{References}

Assembleia da República (1987) Programa do XI Governo Constitucional, Divisão de Edições, Lisbon.

Assembleia da República (1992) Programa do XII Governo Constitucional, Divisão de Edições, Lisbon.

Assembleia da República (1995) Programa do XIII Governo Constitucional, Divisão de Edições, Lisbon.

Assembleia da República (1999) Programa do XIV Governo Constitucional, Divisão de Edições, Lisbon.

Assembleia da República (2002) Programa do XV Governo Constitucional, Divisão de Edições, Lisbon.

Assembleia da República (2005) Programa do XVII Governo Constitucional, Divisão de Edições, Lisbon.

Assembleia da República (2011) Programa do XVII Governo Constitucional, Divisão de Edições, Lisbon.

Baptista, M M (2000) 'O Conceito de Lusofonia em Eduardo Lourenço: Para além do Multiculturalismo 'pós-humanista', paper delivered at the III Seminário Internacional 'Lusografias', University of Évora, Évora, 8-11 November 2000.

Castelo, C (1998) O Modo Português de estar no Mundo, O Luso-Tropicalismo e a Ideologia Colonial Portuguesa (1933-1961). Porto: Afrontamento.

Comunidade dos Países de Língua Portuguesa (1996) Estatutos da Comunidade dos Países de Língua Portuguesa, Cimeira Constitutiva da Comunidade dos Países de Língua Portuguesa, Lisbon, 17 July.

Léonard, Y (1999) 'As Ligações a África e ao Brasil' in Bethencourt, F and Chaudhuri, K História da Expansão Portuguesa. Vol.5, Navarra: Círculo de Leitores.

Lourenço, E (1999) A Nau de Ícaro seguido de Imagem e Miragem da Lusofonia. Lisboa, Gradiva.

Macedo, M L (2013) Da diversidade do mundo ao mundo diverso da lusofonia: a reinvenção de uma comunidade geocultural na sociedade em rede. $\mathrm{PhD}$ dissertation. University of Minho, Braga. 
Maciel, C L (2010) A construção da comunidade lusófona a partir do antigo centro. Micro-comunidades e práticas da lusofonia. PhD dissertation. Universidade Nova de Lisboa.

Margarido, A (2000) A Lusofonia e os Lusófonos: Novos Mitos Portugueses. Lisboa: Edições Universitárias Lusófonas.

Martins, M M (2015) Lusofonia e Interculturalidade - Promessa e Travessia. V.N. Famalicão, Humus.

Martins, M (2004) 'Lusofonia e Luso-tropicalismo. Equívocos e possibilidades de dois conceitos hiper-identitários'. Key note speech delivered at the Inaugural Session of the 10th Brazilian Conference of Portuguese Language, Sao Paulo. Available at https://repositorium.sdum.uminho.pt/bitstream/1822/1075/1/mmartins_LusotropiLusofo nia_2004.pdf

Salgado, S (2014) The Internet and democracy Building in Lusophone Countries. Farnham \& Burlington. Ashgate

Sousa, H (2005) 'The mobilization of the 'Lusophony' concept. The case of RTP' International channels. Paper delivered at the International Association for Media and Communication Research (IAMCR) Conference, Taipei, Taiwan, 26-28 July.

Sousa, H (2000) 'Os media ao serviço do imaginário: uma reflexão sobre a RTP Internacional e a Lusofonia'. Comunicação e Sociedade, n², Vol. 14 (1-2), 305-317. 